\title{
Effect of Sowing Time and Plant Geometry on Growth, Yield and Quality of Chandrasur (Lepidium sativum L.)
}

\author{
Shambhu, K.C. Meena, A. Haldar*, D.K. Patidar and R. Abdul
}

Department of Plantation, Spices, Medicinal and Aromatic Crops, Rajmata Vijayaraje Scindia Krishi Vishwavidyalaya, College of Horticulture, Mandsaur-458 001, Madhya Pradesh, India

*Corresponding author

\section{A B S T R A C T}

\section{Keywords}

Sowing time, Plant geometry, Growth, Yield and Chandrasur

\section{Article Info}

\section{Accepted:}

15 February 2019

Available Online:

10 March 2019
The present study was undertaken to investigate "Effect of sowing time and plant geometry on growth, yield and quality of Chandrasur (Lepidium sativum L.)" was carried out at the "Horticulture Research Farm" College of Horticulture Mandsaur, Rajmata Vijayaraje Scindia Krishi Vishwa Vidyalaya, Gwalior (M.P.) from 2017 to 2018. In this experiment 3 dates of sowing $\left(15^{\text {th }}\right.$ October, $30^{\text {th }}$ October and $15^{\text {th }}$ November) and 3 plant geometry $(20 \times 10 \mathrm{~cm}, 30 \times 10 \mathrm{~cm}$ and $40 \times 10 \mathrm{~cm})$ with 3 replication, the was analyzed by Factorial RBD. The result was found that maximum plant height $(119.60 \mathrm{~cm})$, number of branch per plant (22.30) fresh weight of plant (74.25 g), dry weight of plant (39.99 g), number of racemes per plant (130.13), number of racemes per branch (13.12), racemes length $(31.25 \mathrm{~cm})$, racemes weight $(0.87 \mathrm{~g})$, weight of 1000 seed $(1.88 \mathrm{~g})$, seed yield per plant $(21.15 \mathrm{~g})$, seed yield $(23.97 \mathrm{q} / \mathrm{ha})$ biological yield $(89.14 \mathrm{q} / \mathrm{ha})$, harvest index $(26.89 \%)$ and oil content in seed $(23.83 \%)$ was recorded under treatment $\mathrm{D}_{2} \mathrm{~S}_{2}\left(30^{\text {th }}\right.$ October and $30 \mathrm{~cm}$ ) respectively.

\section{Introduction}

Chandrasur (Lepidium sativum L.) it is also known as asalio and garden cress the plant belongs to family Brassicaceae. It is a fast growing crop that can be ready to eat within 7 days of sowing the seed. The plant has traditional medicinal uses also and it is the source of edible oil that can be used for lighting. In India, it is cultivated as winter crop in selected parts of Rajasthan, Gujarat and Madhya Pradesh for their seeds. The seeds are galactagogue, laxative and diuretic.
Seeds contain phytochemicals that resemble estrogen action. Hence it is used in treating amenorrhoea and irregular menstrual cycles.

It is fed to lactating mothers for improving breast milk production. Seed paste is used as poultice to relieve pain, worm infestation in wounds and useful in skin disorders associated with itching. The mucilage obtained from the seeds is used against intestinal irritations. The leaves are used as diuretic and to treat liver diseases. It is also used as salad for treating Anemia. 


\section{Materials and Methods}

The experiments were carried out during 2017 to 2018, at the Research Farm, College of Horticulture, Mandsaur, RVSKVV, Gwalior (M.P.). Geographically Mandsaur is situated in Western part of Madhya Pradesh between latitude of $23^{\circ} 45^{\prime}$ to $24^{\circ} 13^{\prime} \mathrm{N}$ and longitude of $74^{\circ} 44^{\prime}$ to $75^{\circ} 18^{\prime} \mathrm{E}$ at an altitude of 435.2 Meter above MSL. The annual rainfall is $544.05 \mathrm{~mm}$ most of which is from $20^{\text {th }}$ June to end of September. Dry spell is a common feature due to uneven distribution of rainfall. The soil of experimental field was medium black clay in texture with uniform topography. The treatments consisted of the three sowing time $\left(15^{\text {th }}\right.$ October, $30^{\text {th }}$ October and $15^{\text {th }}$ November) and three plant geometry (20x10 $\mathrm{cm}, 30 \times 10 \mathrm{~cm}$ and 40x10 $\mathrm{cm}$ ) These treatments were sown in Factorial Randomized Block Design with three replications. Observations were recorded under investigation i.e. plant height, number of branch per plant, fresh weight of plant, dry weight of plant, number of racemes per plant, number of racemes per branch, racemes length, racemes weight, weight of 1000 seed, seed yield per plant, seed yield, biological yield, harvest index and oil content in seed.

\section{Results and Discussion}

\section{Effect of sowing time}

Among the growth attributes, sowing time significantly influenced all the growth parameters at different growth stages. Moreover, maximum plant height (11.82, $76.96,115.84$ and $117.852 \mathrm{~cm}$ ), number of branches per plant (17.82, 21.24 and 21.57), fresh weight of plant $(1.36,72.18,82.51$ and $72.81 \mathrm{~g})$ and dry weight of plant $(0.45,14.35$, 28.69 and $38.55 \mathrm{~g}$ ) were observed at 30,60 , $90 \mathrm{DAS}$ and at harvest respectively due to sowing of seeds on $30^{\text {th }}$ October $\left(\mathrm{D}_{2}\right)$ as compared to $15^{\text {th }}$ October $\left(\mathrm{D}_{1}\right)$ and $15^{\text {th }}$ November $\left(D_{3}\right)$.
This might be due to favorable weather conditions prevailed during their growing stages, which influenced the plants to grow taller by increasing cell division and cell elongation, where as the plant height was observed to be less in both early and delayed dates of sowing. Favorable weather conditions helped in formation of more lateral buds resulted in more number of branches per plant these results are consonance with Singh et al., (2009), Choudhary et al., (2013), Umale et al., (2016), Meena et al., (2017), Shanthipriya et al., (2018) in chandrasur and Kumar et al., (2004) in mustard and Bhutia and Sharangi (2018) in fenugreek and Mehmood et al., (2018) and Sultana et al., (2018) in Nigella.

Date of sowing significantly influenced all the yield and yield attributing traits except weight of 1000 seed $(\mathrm{g})$ and harvest index under investigation. Maximum number of racemes per plant (127.14), number of racemes per branch (12.95), racemes length $(29.12 \mathrm{~cm})$, weight of single racemes $(0.83 \mathrm{~g})$, weight of 1000 seed $(1.84 \mathrm{~g})$, yield per plant $(18.75 \mathrm{~g})$, yield (22.44 q/ha), biological yield (87.30 $\mathrm{q} / \mathrm{ha})$, harvest index $(25.70 \%)$ and oil content in seed $(22.53 \%)$ were recorded due in chandrasur on 30th October $\left(\mathrm{D}_{2}\right)$ as compared other two dates of sowing.

The possible reason for lower yield attributes in early sowing might be attributed to unfavorable temperature during the crop season i.e. high temperature at the time of germination in $15^{\text {th }}$ October sowing (D1). The reduction in yield due to delay in sowing might be attributed to less flowering and seed setting on account of unfavorable temperature accompanied by winds coinciding with flowering and seed setting stage of the late sown crop responsible for reduction in seed yield with delayed sowing. Similar results in chandrasur crop were also reported by Choudhary et al., (2013), Sarsawati and Vidya (2013), Meena et al., (2017) and Shanthi Priya 
et al., (2018) and Khobragade et al., (2008), Kumar et al., (2004) in mustard and Bhutia and Sharangi (2018) in fenugreek and Mehmood et al., (2018) and Sultana et al., (2018) in Nigella.

\section{Effect of plant geometry}

Among the various plant geometry, spacing $\mathrm{S}_{2}$ $(30 \mathrm{~cm})$ was exhibited significant maximum value for plant height $(10.53,72.91,109.78$ and $111.26 \mathrm{~cm})$, fresh weight of plant $(1.30$, $62.98,72.00$ and $62.40 \mathrm{~g}$ ) and dry weight of plant $(0.40,9.72,19.44$ and $28.14 \mathrm{~g})$ as compared to $S_{1}(20 \mathrm{~cm})$ and $S_{3}(40 \mathrm{~cm})$ at all the growth stages respectively. However, number of branches (14.63, 16.07 and 16.74) was recorded highest values with the same spacing but non-significantly at all the growth stages respectively as compare to other spacing (Table 1).

This effect might to be due to wider spacing plant get more better light, better availability of space, aeration and soil moisture as well as better nutrient for growth and development of the plant. Similar results were also reported by Meena et al., (2017) in Chandrasur, Suthar et al., (2017) in broccoli, Arif et al., (2012), Kumar et al., (2004) in mustard and Manasa et al., (2017) in red cabbage and Giridhar et al., (2017) in Nigella.

Plant geometry was significantly influence all the yield and yield attributing traits except racemes weight, weight of 1000 seed and harvest index. The maximum number of racemes per plant (115.08), number of racemes per branch (11.06), racemes length $(26.06 \mathrm{~cm})$, racemes weight $(0.77 \mathrm{~g})$, weight of 1000 seed $(1.80 \mathrm{~g})$, seed yield per plant $(17.91 \mathrm{~g})$, seed yield (18.94 q/ha ), biological yield (75.53 q/ha), harvest index $(25.08 \%)$ and oil content in seed $(22.15 \%)$ were observed in $\mathrm{S}_{2}(30 \mathrm{~cm})$ as compare to $\mathrm{S}_{1}(20 \mathrm{~cm})$ and $\mathrm{S}_{3}$ $(40 \mathrm{~cm})$. The plants sown at wider spacing were better exposed to sunlight and also took moisture and nutrients from a larger area which intern could result into vigours plant growth, leading to more number of racemes per plant. These results are in close conformity with the findings of Choudhary et al., (2013) and Meena et al., (2017) in chandrasur, Patel et al., (2017) Kumar et al., (2004) in mustard and Anupama et al., (2017) in Kasuri Methi.

\section{Interaction effect of sowing time and plant geometry}

Under the interaction of sowing time and plant geometry, all the growth attributes were significantly influence under the whole lifespan development except initial stage of growth. However, the highest plant height $(12.63,78.47,119.47$ and $119.60 \mathrm{~cm})$, number of branch per plant (18.13, 22.07 and 22.30) fresh weight of plant $(1.42,74.80,84.40$ and $74.25 \mathrm{~g})$ and dry weight of plant $(0.55,16.93$, 33.87 and $39.99 \mathrm{~g}$ ) were recorded at 30, 60, 90 DAS and at harvest respectively in $\mathrm{D}_{2} \mathrm{~S}_{2}\left(30^{\text {th }}\right.$ October and $30 \mathrm{~cm}$ ) as compare to other combinations. Maximum plant height, number of branches, fresh weight and dry weight were recorded with $\left(D_{2} S_{2}\right)$ 30th October under $30 \times 10 \mathrm{~cm}$ spacing. These results are in conformity with those reported by Meena et al., (2017) in chandrasur crop and Suthar et al., (2017) in broccoli. Sowing time and plant geometry was significantly influence all the yield and yield attributing traits except racemes weight, weight of 1000 seed and harvest index. The maximum number of racemes per plant (130.13), number of racemes per branch (13.12), racemes length $(31.25 \mathrm{~cm})$, single racemes weight $(0.87 \mathrm{~g})$, weight of 1000 seed (1.88 g), seed yield per plant $(21.15 \mathrm{~g})$, seed yield (23.97 q/ha) biological yield (89.14 q/ha), harvest index $(26.89 \%)$ and oil content in seed $(23.83 \%)$ were observed with $\mathrm{D}_{2} \mathrm{~S}_{2}$ (October $30^{\text {th }}$ and 30 $\mathrm{cm}$ ) as compare to other combinations (Table 2). 
Table.1 Effect of different sowing time, plant geometry and their interaction on growth attributes of chandrasur

\begin{tabular}{|c|c|c|c|c|c|c|c|c|c|c|c|c|c|c|c|}
\hline \multirow[t]{2}{*}{ Treatment } & \multicolumn{4}{|c|}{ Plant height $(\mathrm{cm})$} & \multicolumn{3}{|c|}{ Number of branches } & \multicolumn{4}{|c|}{ Fresh weight of plant (g) } & \multicolumn{4}{|c|}{ Dry weight of plant (g) } \\
\hline & $\begin{array}{c}\text { 30 } \\
\text { DAS }\end{array}$ & $\begin{array}{c}\text { 60 } \\
\text { DAS }\end{array}$ & 90 DAS & $\begin{array}{c}\text { AT } \\
\text { Harvest }\end{array}$ & $\begin{array}{c}\text { 60 } \\
\text { DAS }\end{array}$ & $\begin{array}{c}\text { 90 } \\
\text { DAS }\end{array}$ & $\begin{array}{c}\text { AT } \\
\text { Harvest }\end{array}$ & $\begin{array}{c}\text { 30 } \\
\text { DAS }\end{array}$ & $\begin{array}{c}\text { 60 } \\
\text { DAS }\end{array}$ & $\begin{array}{c}90 \\
\text { DAS }\end{array}$ & $\begin{array}{c}\text { AT } \\
\text { Harvest }\end{array}$ & $\begin{array}{c}\text { 30 } \\
\text { DAS }\end{array}$ & $\begin{array}{c}60 \\
\text { DAS }\end{array}$ & $\begin{array}{c}90 \\
\text { DAS }\end{array}$ & $\begin{array}{c}\text { AT } \\
\text { Harvest }\end{array}$ \\
\hline \multicolumn{16}{|c|}{ Sowing dates (D) } \\
\hline$D_{1}-15$ Oct. & 7.00 & 68.22 & 101.07 & 101.75 & 11.56 & 12.29 & 12.91 & 1.28 & 62.09 & 72.56 & 63.22 & 0.39 & 7.42 & 14.84 & 28.96 \\
\hline$D_{2}-30$ Oct. & 11.82 & 76.96 & 115.84 & 117.82 & 17.82 & 21.24 & 21.57 & 1.36 & 72.18 & 82.51 & 72.81 & 0.45 & 14.35 & 28.69 & 38.55 \\
\hline$D_{3^{-}} 15$ Nov & 11.26 & 68.53 & 105.51 & 109.05 & 13.76 & 14.51 & 14.89 & 1.03 & 48.49 & 56.47 & 47.18 & 0.14 & 5.57 & 11.14 & 12.92 \\
\hline S.Em \pm & 0.57 & 0.86 & 0.44 & 0.47 & 0.08 & 0.60 & 0.31 & 0.08 & 0.34 & 0.32 & 0.31 & 0.05 & 0.30 & 0.60 & 0.31 \\
\hline CD at $5 \%$ & 1.70 & 2.57 & 1.31 & 1.40 & 0.25 & 1.79 & 0.91 & 0.24 & 1.01 & 0.97 & 0.93 & 0.15 & 0.89 & 1.79 & 0.93 \\
\hline \multicolumn{16}{|c|}{ Plant geometry $(\mathrm{S})$} \\
\hline$S_{1}-20 \times 10 \mathrm{~cm}$ & 10.36 & 71.98 & 108.53 & 110.58 & 13.96 & 15.96 & 16.20 & 1.11 & 59.59 & 68.65 & 59.77 & 0.23 & 8.33 & 16.67 & 25.51 \\
\hline$S_{2}-30 \times 10 \mathrm{~cm}$ & 10.53 & 72.91 & 109.78 & 111.26 & 14.63 & 16.07 & 16.74 & 1.30 & 62.98 & 72.00 & 62.40 & 0.40 & 9.72 & 19.44 & 28.14 \\
\hline$S_{3^{-}}-40 \times 10 \mathrm{~cm}$ & 9.18 & 68.82 & 104.11 & 106.79 & 14.54 & 16.02 & 16.42 & 1.25 & 60.19 & 70.89 & 61.05 & 0.36 & 9.28 & 18.56 & 26.79 \\
\hline S.Em \pm & 0.57 & 0.86 & 0.44 & 0.47 & 0.08 & 0.60 & 0.31 & 0.08 & 0.34 & 0.32 & 0.31 & 0.05 & 0.30 & 0.60 & 0.31 \\
\hline CD at $5 \%$ & NS & 2.57 & 1.31 & 1.40 & 0.25 & NS & NS & NS & 1.01 & 0.97 & 0.93 & NS & 0.89 & 1.79 & 0.93 \\
\hline \multicolumn{16}{|c|}{ Interaction (DxS) } \\
\hline $\mathbf{D}_{1} \mathbf{S}_{1}$ & 8.43 & 69.20 & 103.67 & 104.80 & 11.50 & 12.93 & 13.07 & 1.01 & 42.90 & 54.80 & 45.49 & 0.13 & 4.97 & 9.93 & 11.23 \\
\hline $\mathbf{D}_{1} \mathbf{S}_{2}$ & 7.30 & 67.00 & 102.13 & 102.77 & 11.27 & 11.80 & 12.37 & 1.07 & 48.21 & 55.49 & 46.53 & 0.16 & 5.47 & 10.93 & 12.27 \\
\hline $\mathbf{D}_{1} \mathbf{S}_{3}$ & 5.27 & 62.20 & 97.40 & 97.68 & 11.90 & 12.13 & 13.30 & 1.02 & 54.37 & 59.12 & 49.53 & 0.14 & 6.27 & 12.54 & 15.27 \\
\hline $\mathbf{D}_{2} \mathbf{S}_{1}$ & 12.00 & 77.40 & 114.47 & 117.53 & 17.53 & 20.47 & 20.80 & 1.08 & 70.70 & 80.26 & 71.00 & 0.17 & 12.53 & 25.07 & 36.74 \\
\hline $\mathbf{D}_{2} \mathbf{S}_{2}$ & 12.63 & 78.47 & 119.47 & 119.60 & 18.13 & 22.07 & 22.30 & 1.42 & 74.80 & 84.40 & 74.25 & 0.55 & 16.93 & 33.87 & 39.99 \\
\hline $\mathbf{D}_{2} \mathbf{S}_{3}$ & 10.66 & 75.00 & 113.60 & 116.33 & 17.80 & 21.20 & 21.60 & 1.41 & 71.03 & 82.87 & 73.18 & 0.45 & 13.57 & 27.15 & 38.92 \\
\hline$D_{3} S_{1}$ & 10.49 & 71.73 & 107.47 & 110.60 & 13.07 & 14.47 & 14.73 & 1.26 & 59.87 & 70.20 & 61.77 & 0.39 & 7.00 & 14.00 & 27.51 \\
\hline $\mathbf{D}_{\mathbf{3}} \mathbf{S}_{2}$ & 11.67 & 73.27 & 107.73 & 111.40 & 14.00 & 14.33 & 14.60 & 1.33 & 62.87 & 73.47 & 63.41 & 0.50 & 7.27 & 14.53 & 29.15 \\
\hline $\mathbf{D}_{3} \mathbf{S}_{3}$ & 11.80 & 66.87 & 101.33 & 105.15 & 14.20 & 14.73 & 15.33 & 1.40 & 63.53 & 74.00 & 64.48 & 0.48 & 8.00 & 16.00 & 30.22 \\
\hline S.Em \pm & 0.98 & 1.48 & 0.76 & 0.81 & 0.15 & 1.03 & 0.53 & 0.14 & 0.59 & 0.56 & 0.54 & 0.09 & 0.52 & 1.03 & 0.54 \\
\hline CD at $5 \%$ & NS & 4.44 & 2.27 & 2.42 & 0.44 & NS & NS & NS & 1.76 & 1.68 & 1.62 & NS & 1.55 & 3.10 & 1.62 \\
\hline
\end{tabular}


Table.2 Effect of different sowing time, plant geometry and their interaction on Yield attributes of chandrasur

\begin{tabular}{|c|c|c|c|c|c|c|c|c|c|c|}
\hline Treatment & $\begin{array}{c}\text { Number } \\
\text { of } \\
\text { racemes } \\
\text { per plant }\end{array}$ & $\begin{array}{c}\text { Number } \\
\text { of } \\
\text { racemes } \\
\text { per } \\
\text { branch }\end{array}$ & $\begin{array}{c}\text { Racemes } \\
\text { length } \\
(\mathrm{cm})\end{array}$ & $\begin{array}{c}\text { Raceme } \\
\text { s weight } \\
\text { (g) }\end{array}$ & $\begin{array}{l}\text { Weight } \\
\text { of } 1000 \\
\text { seed }(g)\end{array}$ & $\begin{array}{l}\text { Seed } \\
\text { yield per } \\
\text { plant (g) }\end{array}$ & $\begin{array}{l}\text { Seed yield } \\
\text { (q/ha) }\end{array}$ & $\begin{array}{l}\text { Biologic } \\
\text { al yield } \\
\text { (q/ha) }\end{array}$ & $\begin{array}{c}\text { Harvest } \\
\text { index } \\
(\%)\end{array}$ & $\begin{array}{c}\text { Oil } \\
\text { content } \\
\text { in seed } \\
\%\end{array}$ \\
\hline \multicolumn{11}{|c|}{ Sowing dates (D) } \\
\hline$D_{1}-15$ Oct. & 93.42 & 8.40 & 21.89 & 0.69 & 1.73 & 14.98 & 16.75 & 67.39 & 24.86 & 20.21 \\
\hline$D_{2}-30$ Oct. & 127.14 & 12.95 & 29.12 & 0.83 & 1.84 & 18.75 & 22.44 & 87.30 & 25.70 & 22.53 \\
\hline D3- 15 Nov & 115.31 & 9.31 & 24.37 & 0.72 & 1.76 & 17.78 & 16.84 & 69.98 & 24.06 & 21.35 \\
\hline S.Em \pm & 0.45 & 0.24 & 0.39 & 0.02 & 0.03 & 0.47 & 0.25 & 0.36 & 2.09 & 0.38 \\
\hline CD at $5 \%$ & 1.36 & 0.73 & 1.18 & 0.07 & NS & 1.42 & 0.75 & 1.06 & NS & 1.13 \\
\hline \multicolumn{11}{|c|}{ Plant geometry (S) } \\
\hline$S_{1}-20 \times 10 \mathrm{~cm}$ & 109.47 & 9.25 & 24.63 & 0.73 & 1.74 & 16.04 & 18.38 & 74.02 & 24.83 & 20.70 \\
\hline$S_{2^{-}}-30 \times 10 \mathrm{~cm}$ & 115.08 & 11.06 & 26.06 & 0.77 & 1.80 & 17.91 & 18.94 & 75.53 & 25.08 & 22.15 \\
\hline$S_{3}-40 \times 10 \mathrm{~cm}$ & 111.32 & 10.35 & 24.69 & 0.75 & 1.77 & 17.56 & 18.70 & 75.12 & 24.89 & 21.24 \\
\hline S.Em \pm & 0.45 & 0.24 & 0.39 & 0.02 & 0.03 & 0.47 & 0.25 & 0.36 & 2.09 & 0.38 \\
\hline CD at $5 \%$ & 1.36 & 0.73 & 1.18 & NS & NS & 1.42 & 0.75 & 1.06 & NS & 1.13 \\
\hline \multicolumn{11}{|c|}{ Interaction (DxS) } \\
\hline $\mathbf{D}_{1} \mathbf{S}_{1}$ & 90.87 & 7.40 & 20.65 & 0.67 & 1.71 & 13.61 & 15.68 & 64.92 & 24.15 & 18.42 \\
\hline $\mathbf{D}_{1} \mathbf{S}_{2}$ & 97.42 & 9.27 & 25.65 & 0.69 & 1.75 & 14.60 & 16.45 & 67.94 & 24.21 & 20.42 \\
\hline $\mathbf{D}_{\mathbf{1}} \mathbf{S}_{\mathbf{3}}$ & 91.97 & 8.52 & 24.55 & 0.70 & 1.72 & 16.71 & 15.82 & 69.29 & 22.83 & 21.80 \\
\hline $\mathrm{D}_{2} \mathrm{~S}_{1}$ & 127.91 & 12.93 & 28.68 & 0.82 & 1.84 & 19.22 & 21.85 & 87.79 & 24.89 & 23.73 \\
\hline $\mathbf{D}_{2} \mathbf{S}_{2}$ & 130.13 & 13.12 & 31.25 & 0.87 & 1.88 & 21.15 & 23.97 & 89.14 & 26.89 & 23.83 \\
\hline $\mathbf{D}_{2} \mathbf{S}_{3}$ & 123.37 & 12.80 & 27.43 & 0.81 & 1.80 & 15.90 & 21.50 & 84.98 & 25.30 & 22.30 \\
\hline $\mathbf{D}_{3} \mathbf{S}_{1}$ & 125.35 & 7.41 & 23.73 & 0.71 & 1.72 & 18.60 & 17.96 & 68.29 & 26.30 & 21.45 \\
\hline$D_{3} S_{2}$ & 100.85 & 10.79 & 21.29 & 0.73 & 1.79 & 17.99 & 18.43 & 73.65 & 25.02 & 21.47 \\
\hline $\mathbf{D}_{3} \mathbf{S}_{\mathbf{3}}$ & 119.73 & 9.73 & 22.91 & 0.74 & 1.76 & 16.76 & 16.41 & 67.92 & 24.16 & 18.84 \\
\hline S.Em \pm & 0.79 & 0.42 & 0.68 & 0.04 & 0.06 & 0.82 & 0.43 & 0.62 & 3.62 & 0.65 \\
\hline CD at $5 \%$ & 2.36 & 1.26 & 2.04 & NS & NS & 2.47 & 1.30 & 1.84 & NS & 1.95 \\
\hline
\end{tabular}


These findings are also supported by Meena et al., (2017) in chandrasur, Suthar et al., (2017) in broccoli and Gawariya et al., (2015) in mustard and Giridhar et al., (2017) in Nigella.

On the basis of one year research It could be concluded that the $\mathrm{D}_{2} \mathrm{~S}_{2}$ (October $30^{\text {th }}$ and 30 $\mathrm{cm}$ ) sowing time and plant geometry and their combination are the best for good plant growth, yield and quality of chandrasur under Malwa condition of Madhya Pradesh.

\section{References}

Anupama, G., Hegde, L.N., Hegde, N.K., Devappa, V., Mastiholi, A.B. and Nishani, S. 2017. Effect of Nitrogen and Spacing Levels on Physiological and Yield Parameters of Kasuri Methi (Trigonella corniculata L.) var. Pusa Kasuri. Int. J. Curr. Microbiol. App. Sci., 6(9): pp. 723-733.

Arif, M., Shehzad, M.A., and Mushtaq, S. 2012. Inter and intra row spacing effects on growth, seed yield and oil contents of white mustard (Sinapis alba L.) under rainfed conditions. Pak. J. Agri. Sci., 49(1): pp. 21-25.

Bhutia, P.H. and Sharangi, A.B. 2018. Influence of dates of sowing and irrigation scheduling on phenology, growth and yield dynamics of fenugreek (Trigonella foenum greacum L.). Legume Research: An International Journal, 41(2).

Choudhary S., Keshwa, G. L., and Yadav, L. R. 2013. Garden cress (Lepidium sativum) growth, productivity and nutrient uptake under different sowing dates, row spacing and nitrogen levels. Indian J. Agron., 58(1): pp. 114-118,

Gawariya, S.C., Chopra, N.K., Chopra, N. and Harika, A.S. 2015. Effect of date of sowing and crop geometry on growth and yield parameters of forage mustard
(Var. Chinese Cabbage). African J. Agri. Res. 10(33): pp. 3292-3295.

Giridhar, K., Reddy, G.S., Kumari, S.S., Kumari, A.L. and Sivasankar, A. 2017. Influence of Sowing Window and Plant Density on Growth, Phenology, Yield and Quality of Nigella sativa L. in Coastal Humid Tropic. Int. J. Curr. Microbiol. App. Sci., 6(9), pp. 499512.

Khobragade, A.M., Ramagya, S., Agashe, D.R. and Waghmare, C.R. 2008. Influence of different sowing dates, plant spacings and genotypes on yield attributes and yield of mustard (Brassica juncea L.). Journal of Soils and Crops, 18(2: pp. 292-297.

Kumar, A., Singh, B., Ashpal, Y. and Yadava, J.S. 2004. Effect of sowing time and crop geometry on tetralocular Indian mustard (Brassica juncea) under southwest haryana. Indian Journal of Agricultural Science, 74(11): pp. 594596.

Manasa, S., Lakshmi, L.M., Sadarunnisa, S. and Rajasekharam, T. 2017. Influence of Different Plant Spacings on Vegetative Growth and Yield of Red Cabbage (Brassica oleracea var. capitata f. rubra). Int. J. Curr. Microbiol. App. Sci., 6(11), pp. 16951700.

Meena B.K., Chouhan G.S., Meena V.K., Singh S. and Meena L. K. 2017. Response of Chandrasur (Lepidium sativum L.) to sowing durations and stand geometries. Chem. Sci. Rev. Let., 6(22): pp. 850-856.

Mehmood, A., Naveed, K., Azeem, K., Khan, A., Ali, N. and Khan, S.M. 2018. Sowing time and nitrogen application methods impact on production traits of Kalonji (Nigella sativa L.). Pure and Applied Biology, 7(2): pp. 476-485.

Patel, A., Singh, A.K., Singh, S.V., Sharma, A., Raghuvanshi, N. and Singh, A.K. 
2017. Effect of Different Sowing Dates on Growth, Yield and Quality of Various Indian Mustard (Brassica juncea L.) Varieties. Int. J. Curr. Microbiol. App. Sci. Special Issue, (4): pp. 71-77.

Saraswathi, G. and Vidya, K. M. 2013. Effect of dates of sowing and fertilizer levels on growth and yield of garden cress (Lepidium sativum L.). International J. Agri. Sci., 9(2): pp. 476-479.

Shanthipriya, A.S., Padma, M., Ramesh, T., Devi, K. S. and Prabhakar, B. N. 2018. Effect of Dates of Sowing on Growth and Physiological Parameters of Garden Cress (Lepidium sativum L.). Int. J. Pure App. Biosci., 6(2): pp. 797-800.

Singh, A., Sikarwar, R.S. and Mishra, U.S. 2009. Effect of different date of sowing on yield and biochemical parameter of Lepidium sativum Linn. Bioved, 4(1): pp. 23-27.

Sultana, S., Das, B., Rudra, B.C., Das, G. and Alam, M. B. 2018. Effect of date of sowing on productivity of black cumin. Int. J. Curr. Microbiol. App. Sci, 7(1): pp. 1796-1800.

Suthar, V., Aravindakshan, K. and Bola, P. K. 2017. Effect of Sowing Date and Spacing on Growth, Yield and Quality of Broccoli (Brassica oleracea var. italica) var. Green Head. Chem. Sci. Rev. Let., 6(21): pp. 209-212.

Umale A.A., Patel, H.K., Kumar, M., Kulkarni, M.V., Patel, J.J. and Kalasare, R.S. 2016. Effect of various dates of sowing and irrigation scheduling based on IW: CPE ratios on growth, biological yield and economics return on cress (Lepidium sativum L.). Journal of Pure and Applied Microbiology, 10(1): pp. 203-207.

\section{How to cite this article:}

Shambhu, K.C. Meena, A. Haldar, D.K. Patidar and Abdul, R. 2019. Effect of Sowing Time and Plant Geometry on Growth, Yield and Quality of Chandrasur (Lepidium sativum L.). Int.J.Curr.Microbiol.App.Sci. 8(03): 1985-1991. doi: https://doi.org/10.20546/ijcmas.2019.803.236 